・研究报告・

\title{
中国南部热带植物区系
}

\author{
朱 华* \\ (中国科学院西双版纳热带植物园综合保护中心, 云南预腊 666303)
}

\begin{abstract}
摘要: 中国的热带地区包括西藏东南部、云南西南到东南部、广西西南部、广东雷州半岛、台湾的南部和海南岛。 依据现有植物区系的记录和资料, 中国的热带地区至少具有野生种子植物227科2,181属12,844种。中国的热带植物 区系以热带和主产热带, 但分布区延伸到亚热带和温带的科为主, 在属的组成上, 也以热带分布属占优势, 并以 热带亚洲分布属所占比例最大, 标志着其热带边缘性质和具有热带亚洲植物区系的特点。因不同地区地质历史及 生态环境的差异, 中国热带植物区系在不同地区的组成和地理成分也有一定差异。总的来说, 我国西南部到东南 部各热带地区的植物区系科和属的相似性分别在 $90 \%$ 和 $64 \%$ 以上，但种的相似性一般低于 $50 \%$ 。具体而言，西藏东 南部与云南东南部显示出具有更多的共同优势科属和更大的植物区系相似性; 云南南部和东南部热带亚洲成分比 例最高, 虽然它们之间在种的相似性上最大, 但在优势的科属上差异较大; 海南植物区系热带成分总体比例最高, 其中又以泛热带分布比例最大。中国热带植物区系在不同地区间演化和发展上的差异与喜马拉雅隆升过程中发生 的地质事件有关, 如印度支那板块向东南逃逸、云南发生地质板块顺时针旋转和位移、云南南部与东南部在地质 历史上曾有的隔离以及海南岛向东南的位移等。
\end{abstract}

关键词: 中国南部; 热带植物区系; 组成; 特征; 起源与演化

\section{Tropical flora of southern China}

Hua Zhu*

Center for Integrative Conservation, Xishuangbanna Tropical Botanical Garden, Chinese Academy of Sciences, Mengla, Yunnan 666303

\begin{abstract}
The Chinese tropical region has generally been recognized to be the area on the northern edge of tropical Asia, and includes southeastern Xizang (Tibet), southern Yunnan, southwestern Guangxi, southern Taiwan, and Hainan Island. Based on present floristic records and data from these tropical areas, 12,844 species of seed plants including 2,181 genera and 227 families, are recognized. The families that are distributed mainly in tropical areas but extended to the temperate zone contribute to the majority of the flora of tropical China, and genera with tropical distributions make up the most of the total flora, which indicate that the flora of tropical areas in China is marginally tropical in nature. The genera with the tropical Asian distribution contributed to the highest portion among the various distribution types, which implies tropical Asian or Indo-Malaysia affinity of the tropical flora of China. The tropical flora of China has conspicuous variations in floristic composition and geographical elements from region to region due to different geological history and ecological environments, although the floristic similarities at the family and generic levels are more than $90 \%$ and $64 \%$, respectively but lower than $50 \%$ at the specific level, among the compared regional floras from southwestern China and southeastern China. We found that there are more similar dominant families and genera, and also higher similarities between families and genera between southeastern Tibet (Xizang) and southeastern Yunnan. The floras of southern and southeastern Yunnan have a higher portion of the tropical Asian elements compared with other tropical floras in China, and although they have the highest similarity at specific level, the dominant families and genera have conspicuous differences between them. The flora of Hainan has the highest ratio of tropical elements, of which the pan-tropical element has the highest portion.
\end{abstract}

收稿日期: 2016-02-26; 接受日期: 2016-08-10

基金项目: 国家自然科学基金面上项目 $(41471051,31170195,41071040)$

* 通讯作者 Author for correspondence. E-mail: zhuh@xtbg.ac.cn 
Differences in characteristics and evolution in these tropical floras could be influenced mainly by historical events occurring with uplift of Himalayas, such as the southeastward extrusion of the Indochina geoblock, clockwise rotation and southeastward movement of Lanping-Simao geoblock, divergent geological histories between southern and southeastern Yunnan, and southeastward movement of Hainan Island.

Key words: southern China; tropical flora; floristic composition; characteristics; origin and evolution

对中国存在热带雨林和热带植物区系的认识 最早见于王启无对中国云南西南部的热带植被的 描述中(Wang, 1939)。20世纪50-60年代, 中国科学 院和云南大学等在做了大量植被调查后, 初步确定 了在云南南部(西双版纳)具有一个热带植物区系 (Fedorov, 1957)和生物地理意义上的真正热带雨林 (Fedorov, 1958), 但它们是与印度、马来西亚的热带

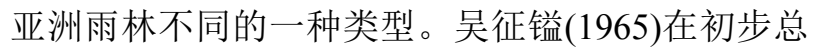
结中国植物区系的特征后提出了中国植物区系的 热带亲缘, 从历史渊源上阐明了中国植物区系具有 热带起源背景, 但并未对中国热带植物区系的分布 区域进行划定。直到20世纪70年代初, 典型的东南 亚热带雨林类型—以龙脑香科植物为标识种的 热带雨林在云南南部和广西西南部被发现, 中国大 陆具有东南亚类型的真正热带雨林这一事实才被 国际上普遍接受(Whitmore，1982，1984，1990), 中 国南部具有一个热带性质的植物区系, 并与热带亚 洲植物区系有直接的联系也被认可。对中国热带地 区植物区系较完整的记录首见于中国科学院华南 植物研究所编著的《海南植物志》(中国科学院华南 植物研究所, 1964-1977)。进一步对中国热带地区的 植物区系、植被的生物地理和生态学研究均证明了 中国存在具有东南亚类型的热带雨林和热带植物 区系(张宏达，1963; 吴征镒，1980，1987; 李锡文， 1995; Hu, 1997; Zhu, 1997, 2008a, b; Zhu et al, 2003; Zhu \& Roos, 2004; Zhu \& Yan, 2009)。

典型的植物区系研究即研究物种的集合, 它是 研究世界某一地区所有野生植物种类的组成和分 布, 探讨其起源和演化历史的科学。具体来说, 研 究一个地区的植物区系就是研究该地区所有野生 植物各分类等级(一般是科、属和种)的组成和地理 成分构成，阐明该植物区的性质和特点，推测其可 能的起源与演化。中国热带植物区系研究主要起始 于对植被或群落类型的物种组成进行分析(张宏达 等, 1957, 张宏达, 1963; 吴征镒, 1980, 1987)。随后, 与植被研究相结合, 针对植被或群落类型的物种组
成进行区系地理成分分析，并结合其生态外貌和结 构特征来综合阐明植被和群落的自然属性。这种把 植物区系地理学方法运用在具体植被和群落类型 的研究上的尝试在云南热带地区得以深入开展 (Zhu, 1994, 1997; 2008b; Zhu et al, 2005, 2006a, b, 2015)。此外, 热带地区的植物区系研究也被广泛运 用于自然保护区的研究，例如云南思茅菜阳河自然 保护区(朱华等, 2006)、广西弄岗自然保护区(梁畴 芬等, 1985) 以及海南的多个自然保护区(丁坦等, 2002; 唐恬等, 2002; 张荣京等, 2007; 符国瑗和洪 小江, 2008)。还有一些是包含了热带地区在内的省 区植物区系研究，如广东植物区系(张宏达，1962; 廖文波和张宏达, 1994)、广西植物区系(苏志尧和张 宏达，1994)、云南植物区系(李锡文，1985; Li \& Walker, 1986)西藏植物区系(李恒和武素功，1983) 等, 这些研究虽然都指明了其南部地区具有热带性 质的植物区，并与热带亚洲植物区系有联系，但除 在李恒和武素功(1983)的研究中详述了西藏南部喜 马拉雅南坡的热带植物区及热带亚洲亲缘外, 其他 的省区研究较少对其热带植物区系进行专门论述。

Zhu (2016a)对云南和台湾植物区系进行了较深入 研究, 特别是对这 2 个省区的热带植物区系成分与 热带亚洲植物区系的关系进行了分析。

本文依据现有的中国热带地区植物区系的记 录和资料, 以典型的植物区系研究方法分析了中国 热带植物区系的基本特征、组成和地理分异以及可 能的起源与演化历史, 以期为中国植物区系研究提 供参考。

\section{1 中国热带植物区系形成与演化的地质历 史背景}

喜马拉雅-青藏高原的隆升对地理、气候的影 响不只限于它本身及周边地区, 而且影响到晚新生 代以来全球气候和大范围的环境变化(Raymo \& Ruddimen, 1992; 施雅风等, 1998, 1999)。在南亚低 空发生的西南季风即由于青藏高原的隆起而形成, 
它对印度、中南半岛及中国西南的热带植被的发育 具有决定性作用(刘东升等, 1998)。

在始新世晚期(距今约45 Ma), 印度板块与亚 欧板块相碰撞, 融合成一体, 但此后喜马拉雅-青 藏高原并未随之强烈隆起, 而是经历了一个漫长的 抬升与夷平过程, 长期处于较低的海拔高度 (1,000-2,000 m)。直到第四纪初, 于3.4 Ma或 $2.5 \mathrm{Ma}$ 才强烈隆升到达现在的高度(潘浴生等, 1998; 潘浴 生, 1999)。喜马拉雅-青藏高原的隆升直接影响了东 亚季风的形成。在青藏高原强烈隆升以前, 虽有主 要受海陆分布影响的古季风, 但很弱。直到 $2.4 \mathrm{Ma}$, 青藏高原强烈隆升到相当高度, 东亚现代季风气候 才形成(施雅风等, 1998)。在喜马拉雅山脉隆升达到 一定的海拔高度 $(6,000 \mathrm{~m})$ 以上时, 南来的暖湿气流 受高大山脉的阻挡, 造成南坡降水丰富, 在中国西 南地区较低海拔处形成温暖湿润的亚热带、热带气 候, 导致了热带雨林植被的发生和热带植物区系的 演化。

由于印度板块与亚洲大陆的碰撞挤压, 引起喜 马拉雅隆升和印度支那板块向东南逃逸, 同时在云 南还发生了地质板块的旋转, 亦即从 4 千万年前的 晚始新世至今, 思茅-兰坪地质板块随着印度支那 板块向东南逃逸, 向南位移了 $800 \mathrm{~km}$, 同时该地质 板块旋转了约 $30^{\circ}$ (Sato et al, 1999, 2007, 2011)。这 些地质事件直接影响了中国西南部热带植物区系 的形成与演化(Zhu, 2012, 2015)。

\section{2 中国的热带地区}

中国的热带地区主要分布在西藏东南部、云南 西南至东南部、广西西南部、广东雷州半岛、台湾 的南部和海南岛, 这些地区在生物地理上均属于热 带亚洲的北部边缘(Zhu, 1997)。尽管中国热带的分 界线充满争议且在运用上有广泛变化, 但气候和自 然地理分带均显示中国的热带除西南部外, 一般位 于北回归线以南(中国科学院地理研究所, 1999)。就 气候而言, 南岭是一条热带分界线。在中国南部(如 广东和广西), 这条界线约在 $24^{\circ}-25^{\circ} \mathrm{N}$, 但在福建 东南部达 $26^{\circ} \mathrm{N}$ (竺可桢和宛敏渭, 1963)。植被与土 壤被认为是比单一气候因子更好的决定生物-气候 分带的指标(任美锷和杨韧章, 1963; 任美锷和曾昭 璇，1991)。依此指标, 中国热带地区北界与北回归 线比较匹配, 但在云南西部可达 $25^{\circ} \mathrm{N}$, 在福建可达 $25^{\circ} 30^{\prime} \mathrm{N}$, 进一步向南, 大约在 $21^{\circ} 30^{\prime} \mathrm{N}$ 。每年 $10^{\circ} \mathrm{C}$ 以上的有效积温有 $8,000^{\circ} \mathrm{C}$ 、最冷月均温 $>16^{\circ} \mathrm{C}$ 的 区域, 也被建议作为中国南部的热带北界(中国科 学院地理研究所, 1959; 丘宝剑和卢其尧, 1961; 丘 宝剑, 1986; 中国科学院地理研究所, 1999), 这条北 界在地理学和气候学上被广泛使用, 该界线以南被 称作真热带(吴绍洪和郑度, 2000)。然而, 在狭义定 义上, 按照Köppen-Geiger的赤道季风气候分类 (Kottek et al, 2006; Peel et al, 2007), 主要依据最低 月均温 $18^{\circ} \mathrm{C} 、$ 年生物温(annual biotemperature) $25^{\circ} \mathrm{C}$, 并具有龙脑香科植物分布, 那么中国热带地区则仅 限于分布在海南省南部和台湾省南部(方精云, 2001; 方精云等, 2002)。

$22^{\circ} 30^{\prime} \mathrm{N}$ 被建议作为中国生物地理上的热带北 界(Zhu et al, 2007; Zhu, 2013)。这条线与目前应用的 中国热带雨林、季雨林北界吻合 (吴征镒, 1980; 侯 学显, 1981, 1988; 张新时, 2007)。在该线以南的区 域尽管 $10^{\circ} \mathrm{C}$ 以上的年有效积温可能稍低于 $8,000^{\circ} \mathrm{C}$, 但严格热带分布的植物如橡胶(Hevea brasiliensis)、 咖啡(Coffea arabica)、菠萝密(Artocarpus heterophyllus)、胡椒(Piper nigrum)、菠萝(Ananas comosus) 等均能够正常生长, 在冬季一般无需保护(徐祥浩, 1982)。在关于热带与亚热带的分界上, 张宏达 (1964)认为把植物生活型和物候型作为标准是可靠 的, 在广东, 热带界线不应超过雷州半岛北部。

在植物区系地理上, 热带分布属占70\%以上区 域(在一些地区植物区系中热带分布属可占到 $80 \%$ 以上)的北界约在 $22^{\circ} 30^{\prime} \mathrm{N}$, 这条界线与中国东南部 年积温 $7,500^{\circ} \mathrm{C}$ 等温线基本一致, 并与中国植被和 植物区系区划匹配，与中国热带雨林及东南亚性质 的热带植物区系分布区域(Zhu, 1997, 2008a, b; Zhu \& Roos, 2004)相符合, 该界线也与世界植物区系分 区的泛北极或东亚植物区系与古热带植物区系的 分界线(Takhtajan, 1978; Wu \& Wu, 1996)相一致。尽 管现在中国的边缘热带, 即 $21^{\circ} 30^{\prime} \mathrm{N}$ 以南, 年积温 $8,000^{\circ} \mathrm{C}$ 以上的区域在地理学和气候学上仍被广泛 使用(中国科学院地理研究所, 1959; 丘宝剑和卢其 尧, 1961; 丘宝剑, 1986; 中国科学院地理研究所, 1999), 但在一些地方植物区系研究中, 热带分布属 占 $80 \%$ 以上并在局部地区具有东南亚类型的热带雨 林的区域, 其北界超出该界线。这也暗示了中国的 热带雨林植被和热带植物区系在地质历史上曾有 
更为广泛的分布。最近在福建 $24^{\circ} 12^{\prime} \mathrm{N}, 117^{\circ} 53^{\prime} \mathrm{E}$ 的 中中新世(Middle Miocene)地层发现了东南亚热带 雨林标识物种龙脑香科植物(Shi \& Li, 2010), 支持 中国东部地区的热带和亚热带常绿阔叶林在中全 新世(Mid-Holocene) 曾北移 (Yu et al，2000; Zhu, 2013), 这与历史上中国南部气候比现在更热的说 法一致(Morley, 1998)。

尽管中国的热带气候分界线仍不能统一，但中 国南部确实存在边缘热带气候(Domroes, 2003)。正 如一些学者所说, 要在中国的热带和亚热带之间划 出一条明显的界线是困难的。我们认为 $22^{\circ} 30^{\prime} \mathrm{N}$ 大 致可以作为中国生物地理上的热带北界(Zhu et al, 2007; Zhu, 2013)。因此, 本文所涉及的中国热带植 物区系即指以 $22^{\circ} 30^{\prime} \mathrm{N}$ 为中国南部和东南部的热带 北界, 但在云南西部热带北界达到 $24^{\circ} 30^{\prime} \mathrm{N}$, 在西 藏南部的深切河谷可达到 $29^{\circ} \mathrm{N}$ (墨脱地区) 的植物 区系。

\section{3 中国热带植物区系组成}

按照中国生物地理上的热带北界, 中国的热带 地区包括西藏东南部、云南西南到东南部、广西西 南部、广东雷州半岛、台湾的南部和海南岛。依据 作者掌握的现有植物区系的记录和资料, 主要包括 西藏东南部、云南西南到东南部、广西西南部和海 南岛。广东雷州半岛的原始植被早已遭到严重干扰 破坏, 虽从残存的一些代表性物种可以看出其原始 植物区系应是热带性质(张宏达等, 1957), 但目前仍 无较全面的研究文献; 台湾的南部也因难以获得较 完整的植物区系资料而在本文中未能涉及。就我们 的资料而言, 中国的热带地区记录到野生种子植物 227科(按APG III系统) 2,181属12,844种(包括亚种 和变种)。

种子植物中, 含 200 种以上的特大科有 14 科, 包括兰科(823种，153属)、豆科(692，118)、禾本科 $(630,170)$ 、茜草科 $(534,81)$ 、菊科 $(484,114)$ 、唇形 科 $(398,75)$ 、樟科 $(345,18)$ 、大戟科 $(335,62)$ 、蓄薇 科(329, 36)、莎草科 $(301,33)$ 、菖麻科 $(274,24)$ 、杜 鹃花科 $(257,14)$ 、壳斗科 $(248,8)$ 和爵床科 $(221,56)$ 。

含 100-200种的大科有 23 科, 包括苦芭苔科 $(186,34)$ 、桑科 $(183,10)$ 、萝藦科 $(179,41)$ 、茶科 $(169$, 13)、姜科 $(167,20)$ 、五加科 $(145,21)$ 、葡萄科 $(142,9)$ 、 芸香科(136, 20)、卫矛科 $(133,12)$ 、玄参科 $(131,35)$ 、
葫芦科(128，26)、毛茛科(128，20)、夹竹桃科(127, 31)、天南星科 $(124,28)$ 、野牡丹科 $(124,19)$ 、紫金 牛科 $(122,5)$ 、番荔枝科 $(118,22)$ 、无患子科 $(116,24)$ 、 旋花科 $(114,23)$ 、蓼科 $(112,8)$ 、忍冬科 $(106,14)$ 、天 门冬科 $(105,16)$ 及棕㭣科 $(101,18)$ 。

这些特大科大部分都是中国及世界上广布的 大科, 在含 100-200种的大科中, 显然以热带-亚热 带分布为主，如苦菅苔科、桑科、萝藦科、茶科、 姜科、五加科、芸香科、夹竹桃科、天南星科、野 牡丹科、番荔枝科等。

有些科在种数上虽不占优势, 但却是构成森林 上、中层乔木的主要科或代表科, 如无患子科、漆 树科、橄榄科、杜英科、柿树科、使君子科、榆科、 桃金娘科、藤黄科、五桠果科等。还有一些科种数 虽不多, 但为群落的特征科, 在群落中通常有较大 重要值, 如龙脑香科、四数木科、肉豆冦科、茶荣 英科、粘木科、山榄科、使君子科、梧桐科、椴树 科(石灰岩地区热带森林)等。

中国热带植物区系主体上以热带和主产热带 的科为主，属于热带性质的植物区系。就不同热带 植被类型而言, 典型热带分布的科主要在热带雨林 中, 热带和主产热带的科在热带雨林中占 $70-80 \%$, 但在热带山地, 有相当数量的主产亚热带和主产温 带的科。中国热带植物区系中含较多种数的科几乎 都是主产热带、分布区延伸到亚热带和温带的科, 而非典型热带科, 标志着中国热带植物区系具有明 显的热带边缘性质。

在原文献记录中, 中国热带植物区系还包括了 作为中国特有科的㾉椒树科和大血藤科, 但㾐椒树 科在Flora of China 和APG IV (APG, 2016) 以及文献 Christenhusz和Byng (2016)中已包括了热带美洲的 Huertea属(4个种)在内, 成为热带亚洲(广义)-热带 美洲分布科。大血藤属 (Sargentodoxa) 在Flora of China 中归属于木通科, 并在越南、老挝也有分布, 本文接受Flora of China 的处理, 这样, 中国热带植 物区系中就没有中国热带地区的特有科了。

在种子植物属中, 榕属(Ficus)、楼梯草属 (Elatostema)、石栋属 (Lithocarpus)、杜鹃属 (Rhododendron) (主要大量出现在西藏东南部和云 南东南部)、悬钩子属(Rubus)、冬青属(Ilex)、石豆 兰属 (Bulbophyllum)、木姜子属 (Litsea)、石䚞属 (Dendrobium)、蒲桃属(Syzygium)、罗伞属(Ardisia)、 
山茶属 (Camellia)、胡椒属(Piper)、崖爬藤属 (Tetrastigma)、菝荔属(Smilax)、栲属(Castanopsis)、 耳草属(Hedyotis)、冷水花属(Pilea)、凤仙花属 (Impatiens)、山矾属(Symplocos) 等为中国热带植物 区系中的主要组成属。与科的情况类似, 这些主要 组成属也以主产热带、分布区延伸到亚热带和温带 的属为最多, 同样亦反映了中国热带植物区系的热 带边缘性质。

\section{4 中国热带植物区系的地理成分}

按中国种子植物科属分布区类型划分 (吴征镒, 1991; 吴征镒等, 2006), 统计了中国热带植物区系 种子植物科属的分布区类型构成。本文主要按 $\mathrm{APG}$ III系统(APG, 2009; Chase \& Reveal, 2009)对中国的 热带地区种子植物区系的科进行了修订, 对修订后 分布区有改变的科, 亦根据情况做了相应调整 (表1)。

从科的地理成分看, 中国热带植物区系中以泛 热带分布的科比例最高, 有 86 科, 占 $37.8 \%$; 其次是 世界分布科, 有 47 科，占 $20.70 \%$; 排名第三的是北 温带分布科, 占 $13.66 \%$; 然后依次是热带亚洲至热 带美洲间断分布科、旧世界热带分布科、热带亚洲 分布科、热带亚洲至大洋洲分布及东亚分布科, 缺
中国特有分布科。热带分布科(类型2-7)合计132科, 占 $58.16 \%$; 温带分布科(类型 8-15)合计 48 科, 占 $21.14 \%$; 热带分布科远优于温带分布科。

从属的地理成分看, 热带分布属(类型2-7)共占 所统计属数的 $67.22 \%$ 。在热带分布属中, 又以热带 亚洲分布属最多, 占所统计属的 $26.04 \%$, 如藤春属 (Alphonsea)、崖摩属(Ammora)、腺蕶木属(Mycetia)、 香花藤属 (Aganosma)、翅子树属(Pterospermum)、银 钩花属(Mitrephora)、绞股兰属 (Gynostemma)、麻楝 属(Chukrasia)、芋属(Colocasia)、山楝属(Aphanamixis)、隐翼属(Crypteronia)、红光树属 (Knema) 等; 其次是泛热带分布属, 占 $15.82 \%$, 如买麻藤属 (Gnetum)、琼楠属(Beilschmiedia)、厚壳桂属 (Cryptocarya)、胡椒属、山柑属(Capparis)、棒柄花 属(Cleidion)、巴豆属(Croton)、薯蓣属(Dioscorea)、 钩藤属(Uncaria)、茌麻属(Boehmeria)、牛奶菜属 (Marsdenia)、崖豆树属(Millettia)、粗叶木属 (Lasianthus)、巴戟属(Morinda)、罗伞属、羊蹄甲属 (Bauhinia) 等; 旧世界热带分布属占7.66\%, 如蒲桃 属、山牵牛属(Thunbergia)、岩棕属(Dracaena)、 露㝸树属 (Pandanus)、翼核果属(Ventilago)、千金 藤属(Stephania)、瓜馥木属(Fissistigma)、暗罗 属(Polyalthia)、竹节树属(Carallia)、橄榄属

\section{表1 中国热带植物区系科属的分布区类型}

Table 1 Areal-types at family and genus levels of the flora in tropical China

\begin{tabular}{lll}
\hline 分布区类型 Areal-types & 科数 No. of family (\%) & 属数 No. of genus (\%) \\
\hline 1 世界分布 Cosmopolitan & $47(20.70)$ & $92(4.22)$ \\
2 泛热带分布 Pantropic & $86(37.89)$ & $345(15.82)$ \\
3 热带亚洲至热带美洲间断分布 Tropical Asia and Tropical America disjuncted & $14(6.17)$ & $57(2.61)$ \\
4 旧世界热带分布 Old World Tropics & $10(4.41)$ & $167(7.66)$ \\
5 热带亚洲至大洋洲分布 Tropical Asia to Tropical Australasia & $9(3.96)$ & $198(9.08)$ \\
6 热带亚洲至热带非洲分布 Tropical Asia to Tropical Africa & $3(1.32)$ & $131(6.01)$ \\
7 热带亚洲分布 Tropical Asia (Indo-Malesia) & $10(4.41)$ & $568(26.04)$ \\
热带成分合计 Subtotal tropical elements (2-7) & $132(58.16)$ & $1,466(67.22)$ \\
8 北温带分布 North Temperate & $31(13.66)$ & $190(8.71)$ \\
9 东亚和北美间断分布 E. Asia and N. America disjuncted & $9(3.96)$ & $79(3.62)$ \\
10 旧世界温带分布 Old World Temperate & $1(0.44)$ & $73(3.35)$ \\
11 温带亚洲分布 Temperate Asia & $0(0.00)$ & $16(0.73)$ \\
12 地中海, 西亚至中亚分布 Mediterranea, W. Asia to C. Asia & $0(0.00)$ & $6(0.28)$ \\
13 中亚分布 C. Asia & $0(0.00)$ & $5(0.23)$ \\
14 东亚分布 E. Asia & $7(3.08)$ & $178(8.16)$ \\
15 中国特有分布 Endemic to China & $0(0.00)$ & $76(3.48)$ \\
温带成分合计 Subtotal temperate elements (8-15) & $48(21.14)$ & $623(28.56)$ \\
总计 Total & $227(100.00)$ & $2,181(100.00)$
\end{tabular}


(Canarium)、弯管花属 (Chassalia)、假海桐属 (Pittosporopsis)、紫玉盘属(Uvaria) 等; 热带亚洲至 大洋洲分布属占 $9.08 \%$, 如银背藤属(Argyreia)、水 锦树属 (Wendlandia)、球兰属(Hoya)、瓜子金属 (Dischidia)、崖爬藤属、黄檀属(Dalbergia)、臭椿属 (Ailanthus)、蒴莲属(Adenia)、苏铁属(Cycas)、五桠 果属(Dillenia)、紫薇属(Lagerstroemia)、翅子藤属 (Loeseneriella)、九里香属(Murraya)、石仙桃属 (Pholidota)、香椿属(Toona) 等; 热带亚洲至热带非 洲分布属占 $6.01 \%$, 如木棉属(Bombax)、大风子属 (Flacourtia)、使君子属( Quisqualis)、逼迫子属 (Bridelia)、龙船花属(Ixora)、豆腐柴属(Premna)、 飞龙掌血属(Toddalia)、尖叶木属(Urophyllum)、羊 角拗属(Strophanthus)、帽芯木属(Mitragyna)、芒属 (Miscanthus) 、藤黄属 (Garcinia) 、香茅属 (Cymbopogon)、榆绿木属(Anogeissus)等。

温带分布属(包括中国特有属)合计占 $28.56 \%$, 其中北温带分布属占 $8.71 \%$, 居于温带分布属的首 位, 如蒿属(Artemisia)、我耳枥属(Carpinus)、华木 属(Betula)、柳属(Salix)、山荣英属(Cornus)、紫堇 属(Corydalis)、松属(Pinus)、花楸属(Sorbus)等; 东 亚分布属有 178 个, 占 $8.16 \%$, 居于温带分布属的第 二位，如狝猴桃属(Actinidia)、射干属(Belamcanda)、 三尖杉属 (Cephalotaxus) 、南酸杳属 (Choerospondias)、蓬莱藤属(Gardneria)、拐菄属 (Hovenia)、藤漆属(Pegia)、茵芋属(Skimmia)、旅节 花属(Stachyurus)、枫杨属(Pterocarya) 等。其他如东 亚和北美间断分布属, 有五味子属(Schisandra)、石 楠属 (Photinia)、紫树属 (Nyssa)、木犀榄属 (Osmanthus)、木兰属 (Magnolia)、十大功劳属 (Mahonia)、八角属(Illicium)、栲属等; 旧世界温带 分布属有筋骨草属(Ajuga)、香薷属(Elsholtzia)、角 盘兰属 (Herminium)、旋覆花属 (Inula)、女贞属 (Ligustrum)、重楼属(Paris) 等。中国特有分布属有 76 个, 占 $3.48 \%$, 如喜树属(Camptotheca)、拟单性木 兰属(Parakmeria)、大血藤属(Sargentodoxa)、瘞椒 树属(Tapiscia)、通脱木属(Tetrapanax)、石笔木属 (Tutcheria)等。

从属的分布区类型构成可以看出, 中国热带植 物区系以热带分布属占优势, 热带性质明显, 并且 有较多热带亚洲或印度一马来西亚植物区系的 特点。

\section{5 中国热带植物区系分异}

由于中国的热带地区主要分布在西藏东南部、 云南西南到东南部、广西西南部、广东雷州半岛、 台湾的南部和海南岛, 它们的植物区系虽主要属于 热带亚洲植物区系的北缘类型, 但从西到东, 因演 化的地质历史不同, 生态环境亦有差异, 其植物区 系的组成尽管基本一致，但分异明显。

表2 比较了西藏东南部、云南南部、云南东南 部、广西西南部及海南热带植物区系的优势科组 成。这 5 个地区植物区系除共同的世界性分布的优 势大科, 如兰科、禾本科、菊科、豆科、茜草科等, 以及主要是泛热带分布的一些大科, 如大戟科、桑 科、樟科及北温带分布的壳斗科外, 西藏东南部和 云南东南部的共同优势科有在喜马拉雅和东亚山 地大量演化的杜鹃花科和五加科, 云南南部和海南 的共同优势科主要是热带分布的番荔枝科。

优势属的情况与优势科基本类似(表3)，但所 比较地区的共同优势属不多，除西藏东南部外, 其他 4 个地区植物区系中榕属均排名第一。其他优 势属虽显示了较高的多样性, 但仍有规律。在西藏 东南部, 杜鹃花属排名第一, 杜鹃花科树萝卜属 (Agapetes)也排名在前。云南东南部也以杜鹃花属为 优势属之一。热带性较强的蒲桃属和粗叶木属在云 南南部和海南排在优势属之列。

表4比较了各地区植物区系属的分布区类型。 除西藏墨脱外, 这些地区植物区系热带成分合计均 在 $69 \%$ 以上, 并以海南最高, 占到 $80.50 \%$ 。如果从具 体分布区类型构成来看, 云南南部和东南部热带亚 洲成分比例最高; 西藏东南部北温带分布和东亚分 布比例最高, 云南东南部次之, 这 2 类成分在海南 也最低。

这些植物区系在优势科和属及地理成分构成 上的分异是地质历史和生境对其植物区系演化影 响的结果。西藏东南部与云南东南部具有一些特别 的共同优势科属，似乎印证了在地质板块碰撞和喜 马拉雅隆升过程中, 云南发生了思茅-兰坪地质板 块顺时针旋转, 也就是云南西北部和西藏东南部向 北移动, 而云南东南部相应发生了南移, 形成一些 云南西北部和西藏东南部与云南东南部的物种的 对应演化和分布(Zhu \& Yan, 2002; 朱华和阎丽春, 2003; Zhu, 2015)。云南南部和东南部热带亚洲成分 
表2 西藏墨脱、云南南部、云南东南部、广西西南部及海南热带植物区系的优势科组成

Table 2 Dominant families in species richness across Chinese tropical areas (Motuo, Xizang; Southern Yunnan; Southeastern Yunnan; Southwestern Guangxi and Hainan)

\begin{tabular}{|c|c|c|c|c|c|c|c|c|c|}
\hline $\begin{array}{l}\text { 西藏墨脱 }^{1} \\
\text { Motuo, Xizang }\end{array}$ & $\begin{array}{l}\text { 种数 } \\
\text { No. of } \\
\text { species }\end{array}$ & $\begin{array}{l}\text { 云南南部 }{ }^{2} \\
\text { Southern Yunnan }\end{array}$ & $\begin{array}{l}\text { 种数 } \\
\text { No. of } \\
\text { species }\end{array}$ & $\begin{array}{l}\text { 云南东南部 }{ }^{3} \\
\text { Southeastern Yunnan }\end{array}$ & $\begin{array}{l}\text { 种数 } \\
\text { No. of } \\
\text { species }\end{array}$ & $\begin{array}{l}\text { 广西西南部 }{ }^{4} \\
\text { Southwestern Guangxi }{ }^{4}\end{array}$ & $\begin{array}{l}\text { 种数 } \\
\text { No. of } \\
\text { species }\end{array}$ & $\begin{array}{l}\text { 海南 }^{5} \\
\text { Hainan }^{5}\end{array}$ & $\begin{array}{l}\text { 种数 } \\
\text { No. of } \\
\text { species }\end{array}$ \\
\hline 兰科 Orchidaceae & 181 & 兰科 Orchidaceae & 377 & 兰科 Orchidaceae & 276 & 豆科 Fabaceae & 163 & 禾本科 Poaceae & 267 \\
\hline 杜鹃花科 Ericaceae & 94 & 豆科 Fabaceae & 261 & 豆科 Fabaceae & 270 & 大戟科 Euphorbiaceae & 105 & 兰科 Orchidaceae & 264 \\
\hline 禾本科 Poaceae & 88 & 茜草科 Rubiaceae & 201 & 茜草科 Rubiaceae & 235 & 茜草科 Rubiaceae & 105 & 豆科 Fabaceae & 230 \\
\hline 菖麻科 Urticaceae & 77 & 禾本科 Poaceae & 189 & 禾本科 Poaceae & 215 & 菊科 Asteraceae & 93 & 茜草科 Rubiaceae & 199 \\
\hline 樟科 Lauraceae & 70 & 大戟科 Euphorbiaceae & 148 & 菊科 Asteraceae & 175 & 兰科 Orchidaceae & 83 & 莎草科 Cyperaceae & 172 \\
\hline 蔷薇科 Rosaceae & 61 & 唇形科 Lamiaceae & 139 & 樟科 Lauraceae & 141 & 禾本科 Poaceae & 79 & 大戟科 Euphorbiaceae & 160 \\
\hline 菊科 Asteraceae & 58 & 菊科 Asteraceae & 137 & 菖麻科 Urticaceae & 134 & 樟科 Lauraceae & 68 & 菊科 Asteraceae & 125 \\
\hline 唇形科 Lamiaceae & 50 & 樟科 Lauraceae & 105 & 大戟科 Euphorbiaceae & 127 & 蓄薇科 Rosaceae & 65 & 唇形科 Lamiaceae & 110 \\
\hline 豆科 Fabaceae & 49 & 菖麻科 Urticaceae & 84 & 蓄微科 Rosaceae & 124 & 菖麻科 Urticaceae & 58 & 樟科 Lauraceae & 103 \\
\hline 茜草科 Rubiaceae & 47 & 姜科 Zingiberaceae & 84 & 壳斗科 Fagaceae & 109 & 壳斗科 Fagaceae & 57 & 萝摩科 Asclepiadaceae & 68 \\
\hline 毛莨科 Ranunculaceae & 35 & 桑科 Moraceae & 83 & 桑科 Moraceae & 104 & 桑科 Moraceae & 47 & 爵床科 Acanthaceae & 66 \\
\hline 五加科 Araliaceae & 31 & 爵床科 Acanthaceae & 77 & 杜鹃花科 Ericaceae & 95 & 芸香科 Rutaceae & 46 & 壳斗科 Fagaceae & 64 \\
\hline 莎草科 Cyperaceae & 29 & 萝摩科 Asclepiadaceae & 66 & 唇形科 Lamiaceae & 91 & 姜科 Zingiberaceae & 46 & 桑科 Moraceae & 60 \\
\hline 壳斗科 Fagaceae & 29 & 莎草科 Cyperaceae & 63 & 莎草科 Cyperaceae & 87 & 萝摩科 Asclepiadaceae & 45 & 番荔枝科 Annonaceae & 54 \\
\hline 天南星科 Araceae & 28 & 葫芦科 Cucurbitaceae & 60 & 爵床科 Acanthaceae & 85 & 苦苣苔科 Gesneriaceae & 45 & 旋花科 Convolvulaceae & 51 \\
\hline 蓼科 Polygonaceae & 28 & 壳斗科 Fagaceae & 60 & 苦苣苔科 Gesneriaceae & 80 & 夹竹桃科 Apocynaceae & 43 & 紫金牛科 Myrsinaceae & 49 \\
\hline 苦苣苔科 Gesneriaceae & 27 & 菩薇科 Rosaceae & 59 & 茶科 Theaceae & 80 & 天门冬科 Asparagaceae & 43 & 菖麻科 Urticaceae & 49 \\
\hline 桑科 Moraceae & 23 & 番荔枝科 Annonaceae & 57 & 天门冬科 Asparagaceae & 67 & 紫金牛科 Myrsinaceae & 42 & 桃金娘科 Myrtaceae & 48 \\
\hline 忍冬科 Caprifoliaceae & 22 & 夹竹桃科 Apocynaceae & 56 & 五加科 Araliaceae & 62 & 唇形科 Lamiaceae & 39 & $\begin{array}{l}\text { 玄参科 } \\
\text { Scrophulariaceae }\end{array}$ & 48 \\
\hline 大戟科 Euphorbiaceae & 22 & 葡萄科 Vitaceae & 56 & 金牛科 Myrsinaceae & 60 & 葡萄科 Vitaceae & 37 & 芸香科 Rutaceae & 42 \\
\hline
\end{tabular}

1 数据引自文献杨宁和周学武(2015); 2 数据引自文献朱华和闰丽春(2012); 3 数据引自文献Zhu和Yan (2009); 4 数据引自文献覃海宁和刘演 (2010), 从中抽提出广西热带地区植物; 5 数据引自文献邢福武等(2012)。

1 Data from Yang \& Zhou (2015); 2 Data from Zhu \& Yan (2012); 3 Data from Zhu \& Yan (2009); 4 Data from Qin \& Liu (2010), the native plants of tropical southwestern Guangxi were abstracted from this reference; 5 Data from Xing et al (2012).

比例最高，可能是随印度支那板块向东南逃逸，它 们的植物区系演化受到热带亚洲植物区系的直接 影响(Zhu, 2008a, 2012)。海南在地理上后来移至中 国最南部, 热带气候形成, 热带植物区系也得以发 展, 热带成分比例最高, 并且以泛热带分布比例最 大(Zhu, 2016b)。另一方面, 云南南部与东南部之间 在优势科属上产生较多差异, 原因可能就是云南南 部与东南部在地质历史上曾有隔离, 在它们之间形 成了生物地理分异(朱华, 2011; Zhu, 2013)。

表 5 比较了西藏东南部、云南南部和东南部、 广西西南部及海南热带植物区系的科、属、种相似 性。其科的相似性均在 $90 \%$ 以上, 属的相似性均在 $64 \%$ 以上，但种的相似性从 $20 \%$ 到 $53 \%$, 反映了它 们的植物区系在起源上(科、属层面)联系密切, 在种 类组成上, 受地理位置、生态环境及地质历史的影 响而分异明显。西藏东南部与云南东南部在科、属 上有最大相似性, 再次印证了思茅-兰坪地质板块
顺时针旋转, 形成云南西北部和西藏东南部与云南 东南部的一些物种对应分布的格局。云南东南部与 广西西南部的植物区系属的相似性最大, 不仅因为 它们的地理位置最近, 也因为它们有类似的地质历 史背景。

我们的研究还发现，云南南部植物区系中有 237 个属在云南东南部热带地区并没有见到，而云 南东南部热带植物区系中有349个属未见于云南南 部，包括57个东亚分布属、53个北温带分布属、22 个中国特有分布属及 17 个东亚-北美间断分布属。 云南南部与东南部热带地区具有类似的热带季风 气候、热带雨林植被和植物区系, 它们的地理位置 也靠近，在种的相似性上最大，但在优势的科属上 却产生较大差异, 可能是因为它们在地质历史上曾 有隔离(云南地质矿产局, 1995), 其植物区系起源背 景不同，这暗示着在云南南部与东南部之间可能存 在一条历史生物地理线——“华线” (朱华, 2011; 
表3 西藏墨脱、云南南部、云南东南部、广西西南部及海南热带植物区系的优势属组成

Table 3 Dominant genera in species richness across Chinese tropical areas (Motuo, Xizang; Southern Yunnan; Southeastern Yunnan; Southwestern Guangxi and Hainan)

\begin{tabular}{|c|c|c|c|c|c|c|c|c|c|}
\hline $\begin{array}{l}\text { 西藏墨脱 }^{1} \\
\text { Motuo, Xizang }\end{array}$ & $\begin{array}{l}\text { 种数 } \\
\text { No. of } \\
\text { species }\end{array}$ & $\begin{array}{l}\text { 云南南部 } \\
\text { Southern } \\
\text { Yunnann }^{2}\end{array}$ & $\begin{array}{l}\text { 种数 } \\
\text { No. of } \\
\text { species }\end{array}$ & $\begin{array}{l}\text { 云南东南部 } \\
\text { Southeastern } \\
\text { Yunnan }^{3}\end{array}$ & $\begin{array}{l}\text { 种数 } \\
\text { No. of } \\
\text { species }\end{array}$ & $\begin{array}{l}\text { 广西西南部 }{ }^{4} \\
\text { Southwestern Guangxi }{ }^{4}\end{array}$ & $\begin{array}{l}\text { 种数 } \\
\text { No. of } \\
\text { species }\end{array}$ & $\begin{array}{l}\text { 海南 }^{5} \\
\text { Hainan }^{5} \\
\end{array}$ & $\begin{array}{l}\text { 种数 } \\
\text { No. of } \\
\text { species }\end{array}$ \\
\hline 杜鹃花属 Rhododendron & 41 & 榕属 Ficus & 65 & 榕属 Ficus & 78 & 榕属 Ficus & 35 & 榕属 Ficus & 41 \\
\hline 楼梯草属 Elatostema & 31 & 石斛属 Dendrobium & 47 & 悬钩子属 Rubus & 53 & 紫金牛属 Ardisia & 21 & 耳草属 Hedyotis & 40 \\
\hline 木姜子属 Litsea & 22 & 石豆兰属 Bulbophyllum & 40 & 秋海棠属 Begonia & 51 & 扁蓄属 Polygonum & 21 & 莆桃属 Syzygium & 36 \\
\hline 扁蓄属 Polygonum & 22 & 扁蓄属 Polygonum & 34 & 楼梯草属 Elatostema & 48 & 石栎属 Lithocarpus & 19 & 冬青 Ilex & 36 \\
\hline 树萝卜属 Agapetes & 19 & 木姜子属 Litsea & 30 & 石栎属 Lithocarpus & 48 & 悬钩子属 Rubus & 19 & 飘拂草属 Fimbristylis & 35 \\
\hline 榕属 Ficus & 19 & 薯蓣属 Dioscorea & 28 & 杜鹃花属 Rhododendron & 42 & 菝葜属 Smilax & 19 & 莎草属 Cyperus & 31 \\
\hline 冷水花属 Pilea & 18 & 莆桃属 Syzygium & 27 & 扁蓄属 Polygonum & 39 & 崖爬藤属 Tetrastigma & 18 & 紫金牛属 Ardisia & 29 \\
\hline 槭属 Acer & 17 & 省藤属 Calamus & 25 & 菝葜属 Smilax & 39 & 山姜属 Alpinia & 17 & 薹草属 Carex & 29 \\
\hline 山胡椒属 Lindera & 16 & 胡椒属 Piper & 25 & 薹草属 Carex & 37 & 珍珠菜属 Lysimachia & 17 & 石柇属 Lithocarpus & 25 \\
\hline 薹草属 Carex & 15 & 秋海棠属 Begonia & 24 & 冬青 Ilex & 35 & 栋属 Quercus & 17 & 粗叶木属 asianthus & 25 \\
\hline 毛兰属 Eria & 15 & 毛兰属 Eria & 22 & 栲属 Castanopsis & 32 & 栲属 Castanopsis & 16 & 山矾属 Symplocos & 25 \\
\hline 虾脊兰属 Calanthe & 13 & 崖爬藤属 Tetrastigma & 22 & 木姜子属 Litsea & 32 & 楼梯草属 Elatostema & 16 & 簕竹属 Bambusa & 22 \\
\hline 山白珠 Gaultheria & 13 & 山蚂蝗属 Desmodium & 21 & 胡椒属 Piper & 29 & 槭属 Acer & 15 & 扁蓄属 Polygonum & 22 \\
\hline 悬钩子属 Rubus & 13 & 楼梯草属 Elatostema & 21 & 崖爬藤属 Tetrastigma & 28 & 冬青 Ilex & 15 & $\begin{array}{l}\text { 青冈属 Cycloba- } \\
\text { lanopsis }\end{array}$ & 21 \\
\hline 柳属 Salix & 13 & 石栋属 Lithocarpus & 21 & 石斛属 Dendrobium & 27 & 冷水花属 Pilea & 15 & 石斛属 Dendrobium & 20 \\
\hline 石豆兰属 Bulbophyllum & 12 & 紫云菜属 Strobilanthes & 21 & 蛇根草属 Ophiorrhiza & 27 & 荚蒾属 Viburnum & 15 & $\begin{array}{l}\text { 石豆兰属 } \\
\text { Bulbophyllum }\end{array}$ & 19 \\
\hline 羊耳蒜属 Liparis & 12 & 栲属 Castanopsis & 20 & 棫属 Acer & 26 & 秋海棠属 Begonia & 14 & 柿属 Diospyros & 19 \\
\hline 菝葜属 Smilax & 12 & 粗叶木属 asianthus & 20 & 紫金牛属 Ardisia & 26 & 铁线莲属 Clematis & 14 & 紫珠属 Callicarpa & 18 \\
\hline 凤仙花属 Impatiens & 11 & 菝葜属 Smilax & 20 & 柃属 Eurya & 26 & 茄属 Solanum & 14 & 菝葜属 Smilax & 18 \\
\hline 蛇根草属 Ophiorrhiza & 11 & 崖豆藤属 Millettia & 19 & 卫矛属 Euonymus & 25 & 山矾属 Symplocos & 14 & 羊耳蒜属 Liparis & 18 \\
\hline
\end{tabular}

数据来源同表2。Data from references as Table 2 .

表4 西藏墨脱、云南南部、云南东南部、广西西南部及海南热带植物区系属的分布区类型所占比例比较 $(\%)$

Table 4 Comparison of areal-types of genera of the floras across Chinese tropical areas (Motuo, Xizang; Southern Yunnan; Southeastern Yunnan; Southwestern Guangxi and Hainan)

\begin{tabular}{|c|c|c|c|c|c|}
\hline $\begin{array}{l}\text { 属分布区类型 } \\
\text { Areal-types of genera }\end{array}$ & $\begin{array}{l}\text { 西藏墨脱 }^{1} \\
\text { Motuo, Xizang }\end{array}$ & $\begin{array}{l}\text { 云南南部 } \\
\text { Southern } \\
\text { Yunnan }^{2}\end{array}$ & $\begin{array}{l}\text { 云南东南部 } \\
\text { Southeastern } \\
\text { Yunnan }^{3}\end{array}$ & $\begin{array}{l}\text { 广西西南部 }{ }^{4} \\
\text { Southwestern } \\
\text { Guangxi }^{4}\end{array}$ & $\begin{array}{l}\text { 海南 }^{5} \\
\text { Hainan }^{5}\end{array}$ \\
\hline 1 世界分布 Cosmopolitan & 7.60 & 4.67 & 4.57 & 5.43 & 5.07 \\
\hline 2 泛热带分布 Pantropic & 16.42 & 20.47 & 17.69 & 20.06 & 23.07 \\
\hline 3 热带亚洲至热带美洲间断分布 & 2.85 & 2.50 & 2.21 & 2.96 & 2.88 \\
\hline \multicolumn{6}{|l|}{ Tropical Asia and Tropical America disjuncted } \\
\hline 4 旧世界热带分布 Old World Tropics & 6.38 & 9.91 & 8.55 & 9.19 & 11.46 \\
\hline 5 热带亚洲至大洋洲分布 & 8.14 & 10.72 & 6.04 & 9.98 & 13.18 \\
\hline \multicolumn{6}{|l|}{ Tropical Asia to Tropical Australasia } \\
\hline \multicolumn{6}{|l|}{ Tropical Asia to Tropical Africa } \\
\hline 7 热带亚洲分布 Tropical Asia (Indo-Malesia) & 16.28 & 27.72 & 27.34 & 23.22 & 23.77 \\
\hline 热带成分合计 Subtotal tropical elements & 54.82 & 77.03 & 69.00 & 69.86 & 80.5 \\
\hline 8 北温带分布 North Temperate & 15.06 & 5.48 & 8.18 & 7.71 & 4.60 \\
\hline 9 东亚和北美间断分布 E. Asia and N. Amer. Disjuncted & 5.16 & 2.58 & 3.46 & 3.95 & 2.49 \\
\hline 10 旧世界温带分布 Old World Temperate & 3.66 & 2.34 & 2.36 & 2.96 & 1.56 \\
\hline 11 温带亚洲分布 Temperate Asia & 0.68 & 0.40 & 0.44 & 0.49 & 0.31 \\
\hline $\begin{array}{l}12 \text { 地中海, 西亚至中亚分布 } \\
\text { Mediterranea, W. Asia to C. Asia }\end{array}$ & 0.54 & 0.24 & 0.22 & 0.30 & 0.16 \\
\hline 13 中亚分布 C. Asia & 0.14 & 0.16 & 0.07 & 0.00 & 0 \\
\hline 14 东亚分布 E. Asia & 11.94 & 5.88 & 8.84 & 7.11 & 3.74 \\
\hline 15 中国特有分布 Endemic to China & 0.41 & 1.21 & 3.02 & 2.17 & 1.48 \\
\hline 温带成分合计 Subtotal temperate elements & 37.58 & 18.29 & 26.59 & 24.7 & 14.34 \\
\hline 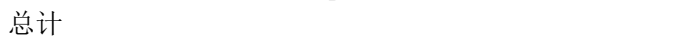 & 100 & 100 & 100 & 100 & 100.00 \\
\hline
\end{tabular}

数据来源同表 2 。Data from references as Table 2 . 
表5 西藏墨脱、云南南部、云南东南部、广西西南部及海南热带植物区系的科、属、种相似性

Table 5 Comparison of floristic similarities at the family, generic and specific levels of the floras across Chinese tropical areas (Motuo, Xizang; Southern Yunnan; Southeastern Yunnan; Southwestern Guangxi and Hainan)

\begin{tabular}{|c|c|c|c|c|}
\hline $\begin{array}{l}\text { 西藏墨脱 Motuo, } \\
\text { Xizang (159科737 } \\
\text { 属1,790种 })^{1}\end{array}$ & $\begin{array}{l}\text { 云南南部 Southern } \\
\text { Yunnan (192科1,240 } \\
\text { 属4,150种 })^{2}\end{array}$ & $\begin{array}{l}\text { 云南东南部 } \\
\text { Southeastern Yunnan } \\
(191 \text { 科1,350属4,987 } \\
\text { 种 })^{3}\end{array}$ & $\begin{array}{l}\text { 广西西南部 } \\
\text { Southwestern Guangxi } \\
(182 \text { 科1,006属2,681种 })^{4}\end{array}$ & $\begin{array}{l}\text { 海南 Hainan } \\
(196 \text { 科 } 1,282 \text { 属 } \\
3,893 \text { 种 })^{5}\end{array}$ \\
\hline
\end{tabular}

\begin{tabular}{|c|c|c|c|c|c|}
\hline \multicolumn{6}{|c|}{ 科相似性 Similarity coefficients at family level } \\
\hline 西藏墨脱 Motuo, Xizang & 100 & & & & \\
\hline 云南南部 Southern Yunnan & 93.71 & 100 & & & \\
\hline 云南东南部 Southeastern Yunnan & 99.37 & 93.19 & 100 & & \\
\hline 广西西南部 Southwestern Guangxi & 94.97 & 93.41 & 95.05 & 100 & \\
\hline 海南 Hainan & 91.19 & 92.71 & 89.00 & 90.66 & 100 \\
\hline \multicolumn{6}{|c|}{ 属相似性 Similarity coefficients at generic level } \\
\hline 西藏墨脱 Motuo, Xizang & 100 & & & & \\
\hline 云南南部 Southern Yunnan & 72.86 & 100 & & & \\
\hline 云南东南部 Southeastern Yunnan & 83.31 & 80.81 & 100 & & \\
\hline 广西西南部 Southwestern Guangxi & 64.99 & 75.45 & 84.59 & 100 & \\
\hline 海南 Hainan & 64.31 & 72.02 & 67.47 & 71.47 & 100 \\
\hline \multicolumn{6}{|c|}{ 种相似性 Similarity coefficients at specific level } \\
\hline 西藏墨脱 Motuo, Xizang & 100 & & & & \\
\hline 云南南部 Southern Yunnan & 32.74 & 100 & & & \\
\hline 云南东南部 Southeastern Yunnan & 39.94 & 53.33 & 100 & & \\
\hline 广西西南部 Southwestern Guangxi & 18.99 & 40.1 & 48.71 & 100 & \\
\hline 海南 Hainan & 17.99 & 36.4 & 32.6 & 34.13 & 100 \\
\hline
\end{tabular}

*两地区相似性系数 $=$ 两地区共同具有的分类群数/含分类群较少的地区的分类群总数 $\times 100 \%$, 数据来源同表 $2 。$

Similarity coefficient between A and B $=$ the number of taxa shared by both A and B / the lowest number of taxa of A or B $\times 100 \%$, Data from references as Table 2 .

Zhu, 2013)。

\section{6 结论与讨论}

喜马拉雅剧烈隆升，东亚季风气候形成，在中 国南方形成温暖湿润的亚热带、热带气候，导致了 热带雨林植被的发生和热带植物区系的演化。

中国的热带地区主要分布在西藏东南部、云南 西南至东南部、广西西南部、广东雷州半岛、台湾 的南部和海南岛。尽管中国热带的分界线充满争议 且在运用上有广泛变化, 但 $22^{\circ} 30^{\prime} \mathrm{N}$ 可作为中国生 物地理上的热带北界。本文涉及的中国热带植物区 系, 即以该线为热带北界, 但在云南西部可达到 $24^{\circ} 30^{\prime} \mathrm{N}$, 在西藏南部的深切河谷可达到 $29^{\circ} \mathrm{N}$ 的 墨脱。

依据现有植物区系的记录和资料, 中国的热带 植物区系具有野生种子植物区系227科 2,181属 12,844种。在组成中国的热带植物区系的特大科中, 大部分都是中国及世界上广布的大科。除特大科外, 中国的热带植物区系以主产热带但分布区延伸到
亚热带和温带的科为主，标志了中国热带植物区系 的热带边缘性质。在中国热带植物区系的大属中, 也以主产热带但分布区延伸到亚热带和温带的属 为主，亦反映了中国热带植物区系的热带边缘 性质。

中国热带植物区系中热带分布的科和属分别 占总科和属数的 $58.00 \%$ 和 $67.22 \%$ (按所有成分统 计)。在热带分布的科中，又以泛热带分布的科比例 最高，占总科数的 $37.80 \%$; 在热带分布的属中，则 以热带亚洲分布属最多，占所统计属的 $26.04 \%$ 。地 理成分构成也明显反映了其热带边缘性质，并且有 较多热带亚洲或印度一马来西亚植物区系的特点。

中国热带植物区系因不同地区地质历史及生 态环境的差异, 其植物区系的组成及地理成分上仍 有一定分异。中国西南部到东南部，各地区植物区 系科的相似性均在 $90 \%$ 以上，属的相似性均在 $64 \%$ 以上，但种的相似性一般低于 $50 \%$ 。这些地区植物 区系除共同的世界性分布的特大科，如兰科、禾本 科、菊科、豆科、茜草科等外，以及主要是泛热带 
分布的一些大科, 如大戟科、桑科、樟科及北温带 分布的壳斗科外, 在西藏东南部和云南东南部均有 在喜马拉雅和东亚山地大量演化的杜鹃花科和五 加科, 在云南南部和海南均有主要是热带分布的番 荔枝科。西藏东南部与云南东南部具有更多的共同 优势科属和相似性, 显然是在喜马拉雅隆升过程 中, 云南发生了地质板块顺时针旋转, 形成云南西 北部和西藏东南部与云南东南部的一些物种对应 演化的格局。海南可能由于其最南的地理位置, 热 带植物区系得以充分发展。

在地理成分构成上, 西藏东南部热带成分比例 相对较低, 北温带和东亚分布比例最高, 这不但因 为其较高的纬度, 而且喜马拉雅的隆升对它也有明 显影响。西藏东南部热带成分相对较低, 这一特征 与孙航和周浙昆(1996，1997)对喜马拉雅东部雅鲁 藏布江大峡弯河谷地区种子植物区系的研究一致, 鉴于这一特征, 他们把墨脱雅鲁藏布江大峡弯地区 归入到泛北极植物区中的东喜马拉雅植物地区。依 据作者对杨宁和周学武(2015)的墨脱植物资料的分 析，其热带分布属占 $54.82 \%$ ，温带分布属占 $37.58 \%$ (表4), 考虑到墨脱地区具有以千果榄仁(Terminalia myriocarpa) 为优势种的热带森林(孙航等, 1997; 杨 宁和周学武, 2015), 笔者仍认为墨脱地区的植物区 系应归为热带性质的植物区系。

从属的分布区类型构成可以看出, 中国热带植 物区系以热带分布属占优势, 热带性质明显, 并且 具有较多热带亚洲或印度-马来西亚植物区系的特 点, 具有热带亚洲亲缘。张宏达 $(1980,1994)$ 承袭古 生代华夏植物区系, 依据三迭纪以来在华南地台及 其毗邻地区发展起来的有花植物区系, 仍主张将其 统归入华夏植物区系, 并认为这里不仅保存了地球 上最丰富的木兰目及其他多心皮类原始被子植物, 还有系统发育过程各个阶段上的许多关键性的科 和目, 是最有可能的被子植物发源地。华夏植物区 系地理范畴很大, 北起黑龙江, 东北部包括日本的 本部和朝鲜半岛, 南部包括印支半岛、马来半岛、 苏门答腊及加里曼丹, 这样的话, 中国热带植物区 系在大范畴上同属于华夏植物区系。

致谢: 问丽春女士帮助建立中国热带植物区系数据 库, 特此致谢!

\section{参考文献}

APG (2009) An update of the Angiosperm Phylogeny Group classification for the orders and families of flowering plants: APG III. Botanical Journal of the Linnean Society, 161, $105-121$.

APG (2016) An update of the Angiosperm Phylogeny Group classification for the orders and families of flowering plants: APG IV. Botanical Journal of Linnean Society, 181, 1-20.

Chang HT (1962) The characteristics of Kwangtung flora. Acta Scientiarum Naturalium Universitatis Sunyatseni, (1), 1-34. (in Chinese) [张宏达 (1962) 广东植物区系的特点. 中山 大学学报(自然科学版), (1), 1-34.]

Chang HT (1963) The Vatica astrotricha forest from Hainan. Acta Phytoecologia et Geobotanica Sinica, 1(2), 142. (in Chinese) [张宏达 (1963) 海南岛的青皮林. 植物生态学 与地植物学资料丛刊, 1(2), 142.]

Chang HT (1964) The boundary of Chinese tropic and subtropic. Acta Phytoecologia et Geobotanica Sinica, 2(1), 139-140. (in Chinese) [张宏达 (1964) 关于热带与亚热带 的分界问题. 植物生态学与地植物学资料丛刊, 2(1), 139-140.]

Chang HT (1980) The origin and development of the Cathaysian flora. Acta Scientiarum Naturalium Universitatis Sunyatseni, (1), 89-98. (in Chinese with English abstract) [张宏达 (1980) 华夏植物区系的起源与发展. 中山大学 学报(自然科学版), (1), 89-98.]

Chang HT (1994) A review on the origin of the Cathaysian flora. Acta Scientiarum Naturalium Universitatis Sunyatseni, 33(2), 1-9. ( in Chinese with English abstract) [张宏达 (1994) 再论华夏植物区系的起源. 中山大学学 报(自然科学版), 33(2), 1-9.]

Chang HT, Zhang CC, Wang BS, Wu HM (1957) The Vegetation of Laichow Peninsula, Kwangtung. Science Press, Beijing. (in Chinese) [张宏达, 张超常, 王伯䔉, 伍 辉民 (1957) 雷州半岛的植被. 科学出版社, 北京.]

Chase MW, Reveal JL (2009) A phylogenetic classification of the land plants to accompany APG III. Botanical Journal of the Linnean Society, 161, 122-127.

Christenhusz MJM, Byng JW (2016) The number of known plants species in the world and its annual increase. Phytotaxa, 261, 201-217.

Ding T, Liao WB, Jin JH, Wang BS (2002) Floristic analysis on the seed plants of Mt. Diaoluo in Hainan Island. Guihaia, 22, 311-319. (in Chinese with English abstract) [丁坦, 廖 文波, 金建华, 王伯荪 (2002) 海南岛吊罗山种子植物区 系分析. 广西植物, 22, 311-319.]

Domroes M (2003) Climatological characteristics of the tropics in China: climate classification schemes between German scientists and Huang Bingwei. Journal of Geographical Science, 13, 271-285.

Fang JY (2001) Re-discussion about the forest vegetation zonation in eastern China. Acta Botanica Sinica, 43, 522-533. (in Chinese with English abstract) [方精云 (2001) 也论我国 
东部植被带的划分. 植物学报, 43, 522-533.]

Fang JY, Song YC, Liu H, Piao SL (2002) Vegetation-climate relationship and its application in the division of vegetation zone in China. Acta Botanica Sinica, 44, 1105-1122. (in Chinese with English abstract) [方精云, 宋永昌, 刘鸿雁, 朴世龙 (2002) 植被气候关系与我国的植被分区. 植物 学报, 44, 1105-1122.]

Fedorov An A (1957) The flora of southwestern China and its significance to the knowledge of the plant world of Eurasia. Komarovskie Chtenija, 10, 20-50. (in Russian)

Fedorov An A (1958) The tropical rain forest of China. Botaniceskjij Žurnal SSSR, 43, 1385-1480. (in Russian with English abstract)

Fu GA, Hong XJ (2008) Flora of vascular plants of Jianfengling, Hainan Island. Guihaia, 28, 226-229. (in Chinese with English abstract) [符国瑗, 洪小江 (2008) 海 南岛尖峰岭的维管植物区系. 广西植物, 28, 226-229.]

Hou XY (1981) A further discussion on the principle and scheme for vegetation regionalization of China. Acta Phytoecologia et Geobotanica Sinica, 5, 290-301. (in Chinese with English abstract) [侯学显 (1981) 再论中国 植被分区的原则和方案. 植物生态学与地植物学资料丛 刊, 5, 290-301.]

Hou XY (1988) Vegetation Geography of China. Science Press, Beijing. (in Chinese) [侯学显 (1988) 中国植被地 理. 科学出版社, 北京.]

Hu YJ (1997) The dipterocarp forest of Hainan Island, China. Journal of Tropical Forest Science, 9, 477-498.

Institute of Geography, Chinese Academy of Sciences (1959) Integrated Physiogeographical Regionalization of China (Draft). Science Press, Beijing. (in Chinese) [中国科学院地 理研究所 (1959) 中国综合自然区划(初稿). 科学出版社, 北京.]

Kottek M, Grieser J, Beck C, Rudolf B, Rubel F (2006) World map of Köppen-Geiger climate classification updated. Meteorologische Zeitschrift, 15, 259-263.

Li H, Wu SK (1983) The regionalization of Xizang (Tibet) flora and the floristic structure of south Himalaya region. Acta Geographica Sinica, 38, 252-261. (in Chinese with English abstract) [李恒, 武素功 (1983) 西藏植物区系区 划和喜马拉雅南部植物地区的区系特征. 地理学报, 38, 252-261.]

Li XW (1985) Floristic study of Yunnan Province. Acta Botanica Yunnanica, 7, 361-382. (in Chinese with English abstract) [李锡文 (1985) 云南植物区系. 云南植物研究, 7, 361-382.]

Li XW, Walker D (1986) The plant geography of Yunnan Province, southwest China. Journal of Biogeography, 13, 367-397.

Li XW (1995) A floristic study on the seed plants from tropical Yunnan. Acta Botanica Yunnanica, 17, 115-128. (in Chinese with English abstract) [李锡文 (1995) 云南热带 种子植物区系. 云南植物研究, 17, 115-128.]
Liang CF, Liang JY, Liu LF, Mo XL (1985) A report on the exploration of the flora of Longgang. Guihaia, 5, 191-209. (in Chinese with English abstract) [梁畴芬, 梁健英, 刘兰 芳, 莫新礼 (1985) 弄岗植物区系考察报告. 广西植物, 5, 191-209.]

Liao WB, Chang HT (1994) A comparison of the spermatophytic flora from Guangdong and its neighbouring regions. Guihaia, 14, 217-226. (in Chinese with English abstract) [廖文波, 张宏达 (1994) 广东种子植物区系与 邻近地区的关系. 广西植物, 14, 217-226.]

Liu DS, Zhang XS, Yuan BY (1998) Uplift and environmental evolution of Qinghai-Xizang (Tibetan) Plateau. In: Formation, Evolution and Development of Qinghai-Xizang (Tibetan) Plateau (eds Sun HL, Zheng D). pp. 179-230. Guangdong Science and Technology Press, Guangzhou. (in Chinese) [刘东升, 张新时, 袁宝印 (1998) 青藏高原隆起 对周边地区的影响. 见: 青藏高原形成演化与发展(孙鸿 烈，郑度主编), 179-230页. 广东科技出版社，广州.]

Morley JR (1998) Palynological evidence for Tertiary plant dispersals in the SE Asian region in relation to plate tectonics and climate. In: Biogeography and Geological Evolution of SE Asia (eds Hall R, Holloway JD), pp. 221-234. Backbuys Publishers, Leiden.

Institute of Geography, Chinese Academy of Sciences (1999) National Nature Atlas of People's Republic of China. Sino Map Press, Beijing. (in Chinese) [中国科学院地理研究所 (1999) 中华人民共和国国家自然地图集. 中国地图出版 社, 北京.]

Pan YS (1999) Formation and uplifting of the Qinghai-Tibet Plateau. Earth Science Frontiers, 6(3), 153-163. (in Chinese with English abstract) [潘浴生 (1999) 青藏高原的形成与 隆升. 地学前缘, 6(3), 153-163.]

Pan YS, Kong XR, Xiong SB (1998) Lithosphere structure, evolution and dynamics of Qinghai-Xizang (Tibetan) Plateau. In: Formation, Evolution and Development of Qinghai-Xizang (Tibetan) Plateau (eds Sun HL, Zheng D), pp. 1-72. Guangdong Science and Technology Press, Guangzhou. (in Chinese) [潘浴生, 孔祥儒, 熊绍柏 (1998) 青藏高原岩石圈结构、演化和动力学. 见: 青藏高原形成 演化与发展(孙鸿烈, 郑度主编), 1-72页. 广东科技出版 社, 广州.]

Peel MC, Finlayson BL, Mcmahon TA (2007) Updated world map of the Köppen-Geiger climate classification. Hydrology and Earth System Sciences, 4, 439-473.

Qin HN, Liu Y (2010) A Checklist of Vascular Plants of Guangxi. Science Press, Beijing. (in Chinese) [覃海宁, 刘 演 (2010) 广西植物名录. 科学出版社, 北京)

Qiu BJ (1986) A new discussion on the regionalization of agroclimate in China. Acta Geographica Sinica, 41, 202-209. (in Chinese with English abstract) [丘宝剑 (1986) 中国农业气候区划新论. 地理学报, 41, 202-209.]

Qiu BJ, Lu QR (1961) Agroclimatic division of tropical and southern subtropical regions in China. Acta Geographica 
Sinica，27，28-37. (in Chinese) [丘宝剑, 卢其尧 (1961) 我国热带-南亚热带的农业气候区划. 地理学报, 27, 28-37.]

Raymo M, Ruddimen W (1992) Tectonic forcing of late Cenozoic climate. Nature, 359, 117-122.

Ren ME, Yang RZ (1963) On some theoretical problems of the physical regionalization in China from a contradictory opinion-re-discussion on the physical regionalization in China. Journal of Nanjing University (Natural Sciences), (3), 1-12. (in Chinese) [任美锷, 杨韧章 (1963) 从矛盾观 点论中国自然区划的若干理论问题一一再论中国自然区 划问题. 南京大学学报(自然科学版), (3), 1-12.]

Ren ME, Zeng ZX (1991) The extent of tropical zone in China. Scientia Geographica Sinica, 11, 101-108. (in Chinese with English abstract) [任美锷, 曾昭璇 (1991) 论中国热带的 范围. 地理科学, 11, 101-108.]

Sato K, Liu YY, Zhu ZC, Yang ZY, Otofuji Y (1999) Paleomagnetic study of middle Cretaceous rocks from Yunlong, western Yunnan, China: evidence of southward displacement of Indochina. Earth and Planetary Science Letters, 165, 1-15.

Sato K, Liu YY, Zhu ZC, Yang ZY, Otofuji Y (2001) Tertiary paleomagnetic data from northwestern Yunnan, China: further evidence for large clockwise rotation of the Indochina block and its tectonic implications. Earth and Planetary Science Letters, 185, 185-198.

Sato K, Liu YY, Wang YB, Yokoyam M, Yoshioka S, Yang ZY, Otofuji Y (2007) Paleomagnetic study of Cretaceous rocks from Pu'er, western Yunnan, China: evidence of internal deformation of the Indochina block. Earth and Planetary Science Letters, 258, 1-15.

Shi GL, Li HM (2010) A fossil fruit wing of Dipterocarpus from the middle Miocene of Fujian, China and its palaeoclimatic significance. Review of Palaeobotany and Palynology, 162, 599-606.

Shi YF, Li JJ, Li BY (1998) Uplift and environmental evolution of Qinghai-Xizang (Tibetan) Plateau. In: Formation, Evolution and Development of Qinghai-Xizang (Tibetan) Plateau (eds Sun HL, Zheng D), pp. 73-138. Guangdong Science and Technology Press, Guangzhou. (in Chinese) [施雅风, 李吉均, 李炳元 (1998) 青藏高原隆升 与环境演化. 见: 青藏高原形成演化与发展(孙鸿烈, 郑 度主编), 73-138页. 广东科技出版社, 广州.]

Shi YF, Li JJ, Li BY, Yao TD, Wang SM, Li SJ, Cui ZJ, Wang FB, Pan BT, Fang XM, Zhang QS (1999) Uplift of the Qinghai-Xizang (Tibetan) Plateau and East Asia environmental change during Late Cenozoic. Acta Geographica Sinica, 54, 10-21. (in Chinese) [施雅风, 李吉 均, 李炳元, 姚檀栋, 王苏民, 李世杰, 崔之久, 王富保, 潘保田, 方小敏, 张青松 (1999) 晚新生代青藏高原的隆 升与东亚环境变化. 地理学报, 54, 10-21.]

South China Institute of Botanical, Chinese Academy of Sciences (1964-1977) Flora of Hainan, Vols. 1-4. Science Press, Beijing. (in Chinese) [中国科学院华南植物研究所
(1964-1977) 海南植物志, 1-4卷. 科学出版社, 北京.]

Su ZY, Chang HT (1994) Genera of Guangxi's flora: an areal type analysis. Guihaia, 14, 3-10. (in Chinese with English abstract) [苏志尧, 张宏达 (1994) 广西植物区系属的地 理成分分析. 广西植物, 14, 3-10.]

Sun H, Zhou ZK (1996) The characters and origin of the flora from the big bend gorge of Yalutsangpu (Brahmabutra) River, eastern Himalayas. Acta Botanica Yunnanica, 18, 185-204. (in Chinese with English abstract) [孙航, 周浙昆 (1996) 喜马拉雅东部雅鲁藏布江大峡弯河谷地区植物区 系的特点和来源. 云南植物研究, 18, 185-204.]

Sun H, Zhou ZK (1997) The phytogeographical affinities and nature of the big bend gorge of the Yalutsangpu Rivers, S.E, Tibet, E. Himalaya. Chinese Journal of Applied and Environmental Biology, 3, 184-190. (in Chinese with English abstract) [孙航, 周浙昆 (1997) 喜马拉雅东部雅 鲁藏布江大峡弯河谷地区种子植物区系的性质和近缘关 系. 应用与环境生物学报, 3, 184-190.]

Sun H, Zhou ZK, Yu HY (1997) The vegetation of the big bend gorge of Yalutsangpu River, S.E. Tibet, E. Himalayas. Acta Botanica Yunnanica, 19, 57-66. (in Chinese with English abstract) [孙航, 周浙昆, 俞宏渊 (1997) 喜马拉雅东部雅 鲁藏布江大峡弯河谷地区植被组成特点. 云南植物研究, 19, 57-66.]

Takhtajan A (Translated by Huang GC) (1988) Floristic Regoins of the World. Sciences Press, Leningrad. Chinese version,. Science Press, Beijing. [黄观程译 (1988) 世界植 物区系区划. 科学出版社, 北京.]

Tang T, Liao WB, Wang BS (2002) Studies on the flora of Wuzhishan, Hainan Island. Guihaia, 22, 297-304. (in Chinese with English abstract) [唐恬, 廖文波, 王伯䔉 (2002) 海南五指山地区种子植物区系的特点. 广西植物, 22, 297-304.]

Wang CW (1939) A preliminary study of the vegetation of Yunnan. Bulletin of the Fan Memorial Institute of Biology, 9(2), 65-125.

Whitmore TC (1982) Fleeting impressions of some Chinese rain forests. Commonwealth Forestry Review, 61, 51-58.

Whitmore TC (1984) Tropical Rain Forest of the Far East, 2nd edn. Clarendon Press, Oxford.

Whitmore TC (1990) An introduction to Tropical Rain Forests. Clarendon Press, Oxford.

Wu SH, Zheng D (2000) New recognition on the boundary between tropical and subtropical zone in the middle section of eco-geographic system. Acta Geographica Sinica, 55, 689-697. (in Chinese with English abstract) [吴绍洪, 郑度 (2000) 生态地理区域系统的热带北界中段界线的新认 识. 地理学报, 55, 689-697.]

Wu ZY (1965) The tropical floristic affinity of the flora of China. Chinese Science Bulletin, 16, 25-33. (in Chinese) [吴征镒 (1965) 中国植物区系的热带亲缘. 科学通报, $16,25-33$.]

Wu ZY (1980) Vegetation of China, pp. 363-397. Science 
Press, Beijing. (in Chinese) [吴征镒 (1980) 中国植被, 363-397页. 科学出版社, 北京.]

Wu ZY (1987) Vegetation of Yunnan, pp. 143-163. Science Press, Beijing. (in Chinese) [吴征镒 (1987) 云南植被, 143-163页. 科学出版社, 北京.]

Wu ZY (1991) The areal-types of Chinese genera of seed plants. Acta Botanica Yunnanica, 13(Suppl. 4), 1-139. [吴 征镒 (1991) 中国种子植物属的分布区类型. 云南植物 研究, 13(增刊4), 1-139.]

Wu ZY, Wu SG (1996) A proposal for a new floristic kingdom (realm) - the Asiatic kingdom, its delineation and characteristics. In: Floristic Characteristics and Diversity of East Asian Plants (eds Zhang AL, Wu SG), pp. 3-42. China Higher Education and Springer Press, Beijing.

Wu ZY, Zhou ZK, Sun H, Li DZ, Peng H (2006) The Areal-types of Seed Plants and Their Origin and Differentiation. Yunnan Science and Technology Press, Kunming. (in Chinese) [吴征镒, 周浙昆, 孙航, 李德铢, 彭华 (2006) 种子植物分布区类型及其起源和分化. 云 南科技出版社, 昆明.]

Xing FW, Zhou JS, Wang FG, Zeng QW, Liu DM (2012) Inventory of Plant Species Diversity of Hainan. Huazhong Science and Technology Press, Wuhan. (in Chinese) [邢福 武, 周劲松, 王发国, 曾庆文, 刘东明 (2012) 海南植物 物种多样性编目。华中科技出版社, 武汉.]

Xu XH (1982) On the demarcation line of tropical and subtropical zones in southern China. Acta Phytoecolgia et Geobotanica Sinica, 6(1), 74-77. (in Chinese) [徐祥浩 (1982) 关于华南的热带与亚热带分界线问题. 植物生态 学与地植物学丛刊, 6(1), 74-77.]

Yang N, Zhou XW (2015) Plants of Motuo. China Forestry Publishing House, Beijing. (in Chinese) [杨宁, 周学武 (2015) 墨脱植物. 中国林业出版社，北京.]

Yu G, Chen X, Ni J, Cheddadi R, Guiot J, Han H, Harrison SP, Huang C, Ke M, Kong Z, Li S, Li W, Liew P, Liu G, Liu J, Liu Q, Liu KB, Prentice IC, Qui W, Ren G, Song C, Sugita S, Sun X, Tang L, Van Campo E, Xia Y, Xu Q, Yan S, Yang X, Zhao J, Zheng Z (2000) Palaeovegetation of China: a pollen data-based synthesis for the mid-Holocene and last glacial maximum. Journal of Biogeography, 27, 635-664.

Yunnan Geology and Mineral Bureau (1995) Atlas of Geology and Palaeogeography of Yunnan. Yunnan Science and Technology Press, Kunming. (in Chinese) [云南地质矿产 局 (1995) 云南岩相古地理图集. 云南科技出版社, 昆 明.]

Zhang RJ, Xing FW, Siu LP, Liu Y, Ye YS, Saichit Ng, Chen HF, Wang FG (2007) Spermatophyte flora of Yinggeling Mountain, Hainan. Biodiversity Science, 15, 382-392. (in Chinese with English abstract) [张荣京, 邢福武, 萧丽萍, 刘演, 叶育石, 吴世捷, 陈红锋, 王发国 (2007) 海南鹦 哥岭的种子植物区系. 生物多样性, 15, 382-392.]

Zhang XS (2007) Vegetation Maps of the People's Republic of China. Geological Publishing House, Beijing. (in Chinese)
[张新时 (2007) 中华人民共和国植被图. 地质出版社, 北京.]

Zhu H (1994) The floristic characteristics of the tropical rain forest in Xishuangbanna. Chinese Geographical Science, 4, 174-185.

Zhu H (1997) Ecological and biogeographical studies on the tropical rain forest of south Yunnan, SW China with a special reference to its relation with rain forests of tropical Asia. Journal of Biogeography, 24, 647-662.

Zhu H (2008a) The tropical flora of southern Yunnan, China, and its biogeographical affinities. Annals of the Missouri Botanical Garden, 95, 661-680.

Zhu H (2008b) Advances in biogeography of the tropical rainforest in southern Yunnan, southwestern China. Tropical Conservation Science, 1, 34-42.

Zhu H (2011) A new biogeographical line between South Yunnan and Southeast Yunnan. Advances in Earth Science, 26, 916-925. (in Chinese with English abstract) [朱华 (2011) 云南一条新的生物地理线. 地球科学进展, 26, 916-925.]

Zhu H (2012) Biogeographical divergence of the flora of Yunnan, southwestern China initiated by the uplift of Himalaya and extrusion of indochina block. PLoS ONE, 7,

Zhe45(Q0.13) Geographical elements of seed plants suggest the boundary of the tropical zone in China. Palaeogeography, Palaeoclimatology, Palaeoecology, 386, 16-22.

Zhu H (2015) Geographical patterns of Yunnan seed plants may be influenced by the Clockwise Rotation of the Simao-Indochina Geoblock. Frontiers in Earth Science, 3, 53. doi:10.3389/feart.2015.00053.

Zhu H (2016a) A biogeographical comparison between Yunnan, Southwest China, and Taiwan, Southeast China, with implications for the evolutionary history of the East Asian Flora. Annals of the Missouri Botanical Garden, 101, $750-771$.

Zhu H (2016b) Biogeographical evidences help revealing the origin of Hainan Island. PLoS ONE, 11, e0151941.

Zhu H, Cao M, Hu HB (2006a) Geological history, flora, and vegetation of Xishuangbanna, southern Yunnan, China. Biotropica, 38, 310-317.

Zhu H, Chai Y, Zhou SS, Wang H, Yan LC (2015) Vegetation, floristic composition and species diversity in a tropical mountain nature reserve in southern Yunnan, SW China with implications to conservation. Tropical Conservation Science, 8, 528-546.

Zhu H, Ma YX, Yan LC, Hu HB (2007) The relationship between geography and climate in the generic-level patterns of Chinese seed plants. Acta Phytotaxonomica Sinica, 45, 134-166.

Zhu H, Roos MC (2004) The tropical flora of S. China and its affinity to Indo-Malesian flora. Telopea, 10, 639-648.

Zhu H, Shi JP, Zhao CJ (2005) Species composition, physiognomy and plant diversity of the tropical montane evergreen broad-leaved forest in southern Yunnan. Biodiversity and Conservation, 14, 2855-2870. 
Zhu H, Wang H, Li BG (2006b) Species composition and biogeography of tropical montane rain forest in southern Yunnan of China. Gardens' Bulletin Singapore, 58, 81-132.

Zhu H, Wang H, Li BG, Sirirugsa P (2003) Biogeography and floristic affinity of the limestone flora in southern Yunnan, China. Annals of the Missouri Botanical Garden, 90, 444-465.

Zhu H, Yan LC (2002) A discussion on biogeographical lines of the tropical-subtropical Yunnan. Chinese Geographical Science, 12, 90-96.

Zhu H, Yan LC (2003) Notes on the realities and significances of the "Tanaka line" and the "Ecogeographical Diagonal line" in Yunnan. Advances in Earth Science, 18, 871-877. (in Chinese with English abstract) [朱华，阎丽春 (2003) 再论“田中线”和“滇西-滇东南”生态地理(生物地理)对角 线”的真实性和意义. 地球科学进展, 18, 871-877.]

Zhu H, Yan LC (2009) Biogeographical affinities of the flora of southeastern Yunnan, China. Botanical Studies, 50, $467-475$.
Zhu H, Yan LC (2012) Native Seed Plants in Xishuangbanna of Yunnan. Science Press, Beijing. (in Chinese) [朱华, 间丽春 (2012) 云南西双版纳野生种子植物. 科学出版社, 北京.]

Zhu H, Zhao CJ, Wang H, Zhou SS, Shi JP, Li BG (2006) A study on the flora of Caiyanghe Nature Reserve in Simao, Yunnan with references to the transition from tropical Asian flora to Eastern Asian flora. Bulletin of Botanical Research, 26(1), 38-52. (in Chinese with English abstract) [朱华, 赵 崇奖, 王洪, 周时顺, 施济普, 李保贵 (2006) 思茅菜阳 河自然保护区植物区系研究——兼论热带亚洲植物区系 向东亚植物区系的过渡. 植物研究, 26(1), 38-52.]

Zhu KZ, Wan MW (1963) Phenology. Scientific Education Press, Beijing. (in Chinese) [竺可桢, 宛敏渭 (1963) 物候 学. 科学教育出版社, 北京.]

(责任编委: 王希华 责任编辑: 黄祥忠) 